\title{
METODE ANALISIS KOMPONEN INDEPENDEN DAN PENGGUNAANNYA PADA DEKOMPOSISI SINYAL ELEKTROENSEFALOGRAFI
}

\author{
Ignatius Danny Pattirajawane ${ }^{1}$ \\ Erfen G. Suwangto 1,2 \\ 1 Lembaga Pengembangan Jejaring Klinik Pratama Atma Jaya, Jakarta \\ 2Fakultas Kedokteran Unika Atma Jaya, Jakarta \\ e-mail: dannyradja@yahoo.co.id
}

\begin{abstract}
Independent component analysis (ICA) is a multivariate statistical method that is used to find factors or independent component from the data. ICA is a further development of factor analysis (FA). The different of ICA to FA is that in FA the distribution of the data is assumed to be normal (gaussian) while it is non-gaussian in ICA. In this paper we will elucidate ICA shortly from the formulation of the problem, the linear modeling of the problem, the solution of the problem through maximum likelihood method and information theory approach, to the formulation of computational algorithm through neural network optimalization of weight matrix. Since one of the common application of ICA is in analysis of biomedical signal, in this paper we will give an illustration of decomposition of electroencephalographic signals in to independent components. This action could help researchers or cliniciansto differentiate brain activities from artifact such as mucles of heart activities. The data samples are taken from open source EEG dataset and would be analyze with EEGLAB which is an open source extension module to Matlab.
\end{abstract}

Keywords: blind source separation, information theory, kullback-leibler divergence, negentropy, non-gaussian distributions

\begin{abstract}
ABSTRAK
Analisis komponen independen (AKI) merupakan metode statistik multivariat yang digunakan untuk menemukan faktor atau komponen independen dari suatu data. AKI merupakan pengembangan lebih lanjut dari analisis faktor (AF). Perbedaannya AKI dengan AF ialah komponen diasumsikan berdistribusi normal (gaussian) pada AF, sedangkan pada AKI komponen diasumsikan berdistribusi non-gaussian. Pada makalah ini akan dipaparkan secara singkat AKI mulai dari perumusan masalah yang memunculkan metode AKI serta permodelan linear yang dihasilkan, pemecahan masalah linear tersebut melalui metode maximum likelihood (ML) dan pendekatan teori informasi, hingga formulasi algoritma komputasi melalui pendekatan optimalisasi matriks beban pada model jaringan syaraf. Karena salah satu penerapan AKI adalah pada analisis sinyal biomedis, dalam makalah ini akan disajikan ilustrasi dekomposisi sinyal elektroensefalografi (EEG) ke dalam komponen independen. Tindakan ini dapat membantu peneliti atau tenaga medis dalam membedakan mana sinyal dari otak dan mana yang merupakan artefak seperti sinyal dari aktivitas otot atau jantung. Data yang digunakan berupa data set EEG sumber terbuka dari daring yang kemudian dianalisis dengan menggunakan perangkat lunak EEGLAB yang merupakan modul tambahan atas perangkat lunak Matlab.
\end{abstract}


Kata kunci: pemisahan sumber buta, teori informasi,divergen kullback-leibler, negentropi, distribusi non-gaussian

Dalam bidang pemrosesan sinyal sering kali analisis diperlukan untuk menentukan sinyalsinyal asli yang berasal dari sumber-sumber tertentu.Pada keadaan tersebut sinyal yang diterima merupakan sinyal-sinyal campuran yang ditangkap oleh sensor.Persoalannya adalah bagaimana sinyal yang tercampur tersebut dipilah-pilah berdasarkan sumber-sumber aslinya.

Ada beberapa ilustrasi dalam kehidupan praktis dari masalah di atas. Yang pertama, sejumlah mikrofon diletakkan di beberapa tempat dalam suatu ruangan yang penuh dengan orangorang yang bercakap-cakap. Dalam keadaan ini setiap mikrofon menangkap berbagai sumber suara dari sejumlah orang. Permasalahannya ialah bagaimana kita menentukan sinyal suara dari setiap orang? Hal ini merupakan masalah klasik penentuan komponen (sinyal) independen yang disebut masalah pesta cocktail (cocktail party problem).

llustrasi kedua berasal dari dunia kedokteran. Dalam pemeriksaan fungsi otak (serebral) digunakan instrumen elektroensepalogram (EEG) yang memiliki sejumlah lead atau channel untuk menangkap aktivitas serebral dari sejumlah lokasi di kepala. Setiap channe/ merekam campuran aktivitas serebral dari berbagai bagian otak maupun artefak otot baik rangka atau jantung yang masuk. Di sini untuk kebutuhan analisis, tenaga medis atau peneliti membutuhkan gambaran sinyal atau aktivitas yang berasal sumber-sumber aslinya tanpa tercampur dengan sumber-sumber lain.

Kedua ilustrasi di atas merupakan sedikit contoh dari penerapan masalah analisis komponen independen (AKI). Dalam AKI akan ditentukan sinyal sumber $s_{1}, s_{2}, \ldots, s_{m}$ dari sinyal yang ditangkap sensor (diobservasi) $x_{1}, x_{2}, \ldots, x_{n}$. Permasalahan ini pertama kali diajukan oleh Herault \& Jutten (1986) dengan menambah beberapa hipotesis.Pertama, sinyal sumber dianggap independen secara statistik dan oleh karena itu ia dinamakan, oleh Comon (1994) kemudian, komponen independen. Kedua, sinyal observasi merupakan pencampuran secara linear dari sinyal sumber.

Dalam ekspresi matematis, bila $\boldsymbol{x}$ merupakan vektor sinyal terobservasi dan $\boldsymbol{s}$ merupakan vektor sinyal sumber, maka hubungan keduanya dapat dinyatakan sebagai berikut:

$\boldsymbol{x}=A \boldsymbol{s}$

Dalam (1) $\boldsymbol{x}=\left(\begin{array}{lll}x_{1} x_{2} & \ldots & x_{n}\end{array}\right)^{T}$ adalah vektor sinyal terobservasi yang ditangkap nlead atau channel, $\boldsymbol{s}=\left(\begin{array}{llll}s_{1} s_{2} & \ldots & s_{m}\end{array}\right)^{T}$ vektor sinyal sumber yang berasal dari $m$ sumber, dan $A$ merupakan matriks penyampur (mixing matrix) berukuran $n \times m$.

Dalam praktik nyata umumnya sinyal yang dianalisis merupakan sinyal yang dicuplik atau sampel dengan frekuensi sampel tertentu sehingga merupakan sinyal diskrit. Vektor $\boldsymbol{x}$ diperoleh dalam bentuk data deret waktu (time series) sebanyak $N$ observasi sehingga (1) dapat ditulis sebagai

$\boldsymbol{x}(t)=A \boldsymbol{s}(t), t=1,2, \ldots N$

Namun sering kali ekspresi (1) yang lebih banyak digunakan.

Tujuan AKI adalah menentukan $\boldsymbol{s}$ melalui data yang terobservasi $(\boldsymbol{x})$.Di sini nilai matriks $A$ juga tidak diketahui.Karena pengetahuan kita tentang $\boldsymbol{s}$ dan $A$ sangat minim, maka permasalahan AKI juga sering dikaitkan dengan permasalahan pemisahan sumber buta (blind source separation).

Dalam statistik multivariat permasalahan (1a) dapat diselesaikan dengan analisis faktor (AF) dengan syarat faktor-faktor atau variabel laten yang diperoleh berdistribusi normal (Gaussian). Sedangkan pada AKI variabel laten, atau dalam hal ini komponen independennya berdistribusi nongaussian. Dalam dua kasus ilustrasi di atas sinyal suara manusia maupun sinyal EEG sering kali 
berdistribusi non-gaussian yang berkategori supergaussian dengan kurtosis positif (Sanei \& Chambers, 2007, Stone, 2004, Hyvärinen, Karhunen \& Oja, 2001, Bell \& Sejnowski, 1995).

Pada AF diidentifikasi faktor-faktor yang saling ortogonal dan saling tak berkolerasi yang melatarbelakangi suatu data dengan menggunakan analisis komponen utama (principal component analysisatau PCA). PCA melakukan transformasi linear berupa rotasi terhadap data terobservasi. Dan secara matematis penentuan matriks rotasi tersebut diperoleh dengan melakukan dekomposisi nilai singular (singular value decomposition) pada matriks kovarians dari data (Sanei \& Chambers, 2007, Hyvärinen, Karhunen\& Oja, 2001). Adapun algoritme komputasi dekomposisi nilai singular telah dibahas secara panjang lebar dalam Golub \& van Loan(1996).

Meski AF tidak dapat digunakan untuk memperoleh komponen independen yang berdistribusi non-gaussian, namun dalam praktiknya metode ini digunakan pada pra-pemrosesan (pre-processing) sinyal untuk menyingkirkan bising (noise). Jika $C$ adalah matriks kovarians dari data terobservasi $\boldsymbol{x}(t)$, maka $C=E\left\{\boldsymbol{x} \boldsymbol{x}^{T}\right\}$ yang merupakan matriks simetris berdasarkan dekomposisi nilai singular $C$ dapat difaktorkan menjadi (Rao, 2002, Hyvärinen, Karhunen \& Oja, 2001, Comon, 1994):

$C=E D E^{T}$

Pada (2) $D$ adalah matriks diagonal nilai eigen dari $C$ dan $E$ merupakan matriks dengan kolom vektor eigen. Kemudian dengan mengambil

$$
V=D^{-1 / 2} E^{T}
$$

maka pra-pemrosesan sinyal berupa pemutihan data dapat diperoleh dengan mentransformasikan vektor data terobservasi dengan matriks $V$

$$
\boldsymbol{z}=V \boldsymbol{x}
$$

Pemutihan (whitening) data ini menghilangkan bising dan membuat variabel-variabel laten yang diperoleh menjadi tidak berkorelasi. Selanjutnya dengan mensubstitusikan (1) pada (4) diperoleh

$$
\boldsymbol{z}=V \boldsymbol{x}=V A \boldsymbol{s}
$$

Pemrosesan sinyal untuk memperoleh komponen independen bertolak dari data sinyal terobservasi yang sudah diputihkan. Perlu dicatat bahwa perlakuan pra-pemrosesan terhadap data selain pemutihan adalah pemusatan (centering) data. Tindakan ini dilakukan dengan mengurangi tiap nilai observasi suatu variabel dengan nilai rata-ratanya. Dalam pembahasan di makalah ini kami mengasumsikan bahwa data telah dipusatkan.

Agar (4a) dapat diselesaikan, maka matriks $V A$ harus memiliki invers sehingga terdapat matriks $W=(V A)^{-1}$ sehingga

$$
\boldsymbol{s}=W \mathbf{z}
$$

Matriks $W$ disebut matriks pemisah (unmixing matrix) yang merupakan kebalikan dari matriks $A$. Bila matriks $A$ mencampur signal data terobservasi, maka matriks $W$ memisahkan sinyal data yang sudah diputihkan ke dalam komponen-komponen yang saling independen.

Namun karena nilai entri matriks $A$ tidak diketahui, maka harus ditambahkan kriteria lagi agar (5) dapat diselesaikan. Untuk itu kita perlu menggunakan asumsi-asumsi AKI untuk mengkonstruksi kriteria tersebut. Adapun asumsi-asumsi yang dimaksud adalah bahwa sinyal data sumber adalah saling independen satu sama lainnya dan berdistribusi non-gaussian (catatan: dalam permodelan linear yang tidak memiliki bising atau noiseless seringkali diperbolehkan hanya satu komponen saja yang berdistribusi gaussian).

Pada perkembangan selanjutnya, kontribusi diberikan oleh Comon (1994), yaitu mengunakan metode dari teori informasi untuk mengukur derajat keindependenan dan ke-non- 
gaussian-an data. Ukuran yang pertama adalah yang mengukur jarak antara densitas probabilitas bersama (mutual) suatu vektor random dengan densitas probabilitas bersama bila diasumsikan komponen vektornya saling independen.Ukuran jarak itu menggunakan divergensi kullback-leibler. Untuk menentukan sejauh mana penyimpangan distribusi probabilitas suatu variabel random dari variabel random yang berdistribusi gaussian digunakan ukuran negentropi.

Dalam teori informasi variabel yang berdistribusi gaussian dianggap memiliki nilai entropi terbesar (Cover\& Thomas, 2006, Papoulis, 1996). Dan karena teori limit pusat yang menyatakan bahwa jumlah variabel-variabel random independen akan menghasilkan variabel random yang distribusinya semakin mendekati distribusi normal (Gauss), maka diperoleh suatu hubungan antara independensi antar variabel-variabel random dengan ukuran non-gaussian mereka. Memperbesar independensi berarti meminimalkan divergensi kullback-leibler atau memaksimalkan negentropi. Masalah AKI kini berkembang menjadi masalah optimalisasi.

Dalam makalah ini akan dibahas pendekatan (metode) yang digunakan untuk menyelesaikan masalah optimalisasi, yakni metode Bell-Sejnowski yang menggunakan teori informasi dan jaringan saraf. Selanjutnya akan dipaparkan algoritme yang digunakan untuk menentukan matriks $W$ dan vektor $\boldsymbol{z}$. Aplikasi AKI pada pemrosesan sinyal EEG akan dibahas dalam tinjauan pustaka setelah pembahasan metode. Kemudian akan ditampilkan ilustrasi kasus pemrosesan sinyal EEG.

\section{METODE}

Sejak masalah AKI diajukan pertama kali oleh Herault dan Jutten pada tahun 1986, sampai sekarang sudah banyak pendekatan dalam menyelesaikan masalah optimalisasi untuk menentukan nilai matriks $W$. Dalam bidang pemrosesan sinyal EEG Sanei dan Chambers (2007) menyebutkan beberapa pendekatan yang dapat digunakan, di antaranya: Teori informasi dalam metode infomax Bell-Sejnowski, penggunaan statistik tingkat tinggi pada diagonalisasi kumulan orde keempat (JADE), penggunaan statistik orde kedua (SOBI), pendekatan titik tetap cepat (Fast/CA) yang menghasilkan algoritme yang popular oleh Hyvärinen \& Oja, dan pendekatan waktu-frekuensi.

Pada tahun 2010 telah terbit Handbook of Blind Source Separation dengan editor Pierre Comon dan Christian Jutten. Dalam buku tersebut telah dirangkum berbagai metode dan pendekatan yang digunakan dalam AKI yang dihasilkan selama dua puluh lima tahun sebelumnya. Tidak semua metode dibahas dalam makalah ini.Hanya Metode infomax Bell-Sejnowski yang memberikan tonggak penting dalam sejarah AKI akan diangkat dalam makalah ini.

\section{Ekuivalensi Pendekatan Teori Informasi dan Metode Likelihood}

Berdasarkan hubungan antar variabel random yang dinyatakan pada (5), maka hubungan fungsi distribusinya dapat dinyatakan dengan persamaan transformasi berikut:

$$
p_{z}(\mathbf{z})=\left|\frac{\partial \boldsymbol{s}}{\partial \mathbf{z}}\right| \prod_{i} p_{i}\left(s_{i}\right)=|\operatorname{det} W| \prod_{i} p_{i}\left(\boldsymbol{w}_{i} \mathbf{z}\right)
$$

Di sini $\left|\frac{\partial s}{\partial z}\right|=W$ merupakan jacobian transformasi linear (5). Kemudian kita bentuk fungsi likelihood dalam $W$ :

$$
L(W)=\prod_{t=1}^{N}\left(|\operatorname{det} W| \prod_{i=1}^{m} p_{i}\left(\boldsymbol{w}_{i}^{T} \boldsymbol{z}(t)\right)\right.
$$

dan fungsi log-likelihood: 


$$
\log L(W)=\sum_{t=1}^{N} \sum_{i=1}^{m} \log p_{i}\left(\boldsymbol{w}_{i}^{T} \boldsymbol{z}(t)\right)+N \log |\operatorname{det} W|
$$

Kemudian dengan membagi kedua ruas pada (8) dengan jumlah observasi sebesar $N$ dan menerapkan konsep nilai ekspektasi probabilitas kita memperoleh hubungan:

$$
\frac{1}{N} \log L(W)=E\left\{\sum_{i=1}^{m} \log p_{i}\left(\boldsymbol{w}_{i}{ }^{T} \boldsymbol{z}(t)\right)\right\}+\log |\operatorname{det} W|
$$

Selanjutnya akan ditunjukan bahwa fungsi log-likelihood pada (9) dapat juga dicapai melalui pendekatan teori informasi. Pertama-pertama akan dihitung nilai entropi diferensial fungsi distribusi sinyal data sumber:

$$
H(\boldsymbol{s})=-\int p_{\boldsymbol{s}}(\boldsymbol{s}) \log p_{\mathbf{z}}(\boldsymbol{s}) d \boldsymbol{s}=-E\left\{\log p_{\boldsymbol{s}}(\boldsymbol{s})\right\}
$$

Dengan memasukkan transformasi (6) maka akan diperoleh

$$
\begin{array}{r}
H(\boldsymbol{s})=-E\left\{\log \left(|\operatorname{det} W| \prod_{i} p_{i}\left(\boldsymbol{w}_{i} \mathbf{z}\right)\right)\right\} \\
=-\left(E\left\{\sum_{i=1}^{m} \log p_{i}\left(\boldsymbol{w}_{i} \mathbf{z}\right)\right\}+\log |\operatorname{det} W|\right)
\end{array}
$$

Bila persamaan (11) kita kaitkan dengan persamaan (9) maka kita akan memperoleh kaitan pendekatan likelihood dalam statistik dengan teori informasi (entropi) dalam ekspresi:

$$
\frac{1}{N} \log L(W)=-H(\boldsymbol{s})
$$

\section{Algoritma optimalisasi melalui pendekatan jaringan saraf}

Dalam menentukan matriks $W$ kita akan memperbaharui matriks pemisah atau matriks beban $W$. Bila $W_{t}$ adalah matriks beban untuk data observasi ke $t$ dan $W_{t-1}$ adalah matriks beban untuk data observasi ke $t-1$ maka pembaharuan (update) matriks beban dapat dinyatakan dalam persamaan iterasi sebagai berikut:

$$
W_{t}=W_{t-1}+\Delta W
$$

$t=1,2, \ldots, N$ adalah nilai waktu observasi. Bentuk (13) telah dikenal dalam jaringan neural (neural network) (Widodo, 2012). Dalam konteks AKI $\Delta W$ berhubungan dengan fungsi kontras atau

$$
W_{t}=W_{t-1}+\alpha_{t} \frac{\partial \Psi(W)}{\partial W}
$$

$\alpha(t)$ adalah laju belajar (learning rate) dalam konsep jaringan saraf atau panjang langkah (step size) dalam konsep pemrograman non-linear metode gradien (Kerami\&Silaban, 2009). $\Psi(W)$ adalah fungsi kontras yang merupakan generalisasi dari ukuran kenon-gaussianan.Dengan demikian pendekatan jaringan saraf pada (14) juga identik dengan pendekatan metode gradien pada pemrograman non-linear. Pendekatan jaringan saraf telah lama digunakan sejak Herault \& Jutten (1986) serta Bell \& Sejnowski (1996).

Dalam makalah ini akan dibahas pendekatan infomax Bell-Sejnowski. Adapun fungsi kontras yang digunakan adalah likelihood atau $\Psi\left(p_{s}\right)=\frac{1}{N} \log L(W)$ seperti pada bentuk (9). Dengan demikian 


$$
\frac{\partial \Psi(W)}{\partial W}=\frac{1}{N} \frac{\partial \log L(W)}{\partial W}
$$

Hyvärinen, Karhunen, \& Oja (2001) menyatakan

$$
\frac{1}{N} \frac{\partial \log L(W)}{\partial W}=\left[W^{T}\right]^{-1}+E\left\{g(W \mathbf{z}) \mathbf{z}^{T}\right\}
$$

$g(\boldsymbol{s})=\left(g_{1}\left(s_{1}\right), g_{2}\left(s_{2}\right), \ldots, g_{m}\left(s_{m}\right)\right)$ adalah fungsi skor dari fungsi distribusi $\boldsymbol{s}$ dengan

$$
g_{i}=\left(\log p_{i}\right)^{\prime}=\frac{p_{i}^{\prime}}{p_{i}}
$$

Untuk distribusi $\boldsymbol{s}$ yang supergaussian, maka pendekatan untuk fungsi $g(\boldsymbol{s})$ adalah

$$
g(\boldsymbol{s})=-2 \tanh \boldsymbol{s}
$$

Bukti (15) - (17) dapat dilihat pada Stone (2004).

Akhirnya memasukkan (15a) dan (17) pada (14) kita memperoleh persamaan iterasi yang menjadi dasar penulisan algoritma penentuan matriks pemisah $W$

$$
\begin{aligned}
W_{t} & =W_{t-1}+\alpha_{t}\left(\left[W_{t-1}^{T}\right]^{-1}+E\left\{g\left(W_{t-1} z\right) z^{T}\right\}\right) \\
& =W_{t-1}+\alpha_{t}\left(\left[W_{t-1}^{T}\right]^{-1}+E\left\{-2 \tanh \left(W_{t-1} z\right) z^{T}\right\}\right) \\
& =W_{t-1}+\alpha_{t}\left(\left[W_{t-1}^{T}\right]^{-1}+-\frac{2}{N} \sum_{t=1}^{N} \tanh \left(W_{t-1} z\right) z^{T}\right)(25)
\end{aligned}
$$

\section{TINJAUAN PUSTAKA KAJIAN EEG KUANTITATIF}

Kajian sinyal EEG secara kuantitatif umumnya terbagi atas dua bagian besar yakni EEG latar (background EEG) dan potensial terkait-peristiwa atau event-related potensial (untuk selanjutnya disebut ERP) (Kropotov, 2009, Sanei \& Chambers, 2007).EEG latar memandang sinyal aktivitas otak tanpa rangsangan atau tanpa stimulasi, sedangkan ERP memperhatikan perubahan potensial listrik otak akibat stimulasi.

Pada EEG latar ada beberapa gelombang otak khas yang sering menjadi kajian di antaranya gelombang alfa $(8-13 \mathrm{~Hz})$, beta $(13-30 \mathrm{~Hz})$, theta $(4-8 \mathrm{~Hz})$ dan delta $(0,5-4 \mathrm{~Hz})$. Salah satu yang terpenting adalah gelombang alfa yang pertama kali ditemukan oleh psikolog Jerman Hans Berger pada tahun 1929. Gelombang ini ditemukan pada bagian otak yang dalam keadaan sadar namun dalam keadaan "istirahat" atau tidak terstimulasi (Kropotov, 2009).

Gelombang alfa memiliki beberapa variasi di antaranya ritme-mu.Nama gelombang ini diambil dari huruf yunani $(\mu)$ karena bentuk gelombangnya dianggap menyerupai huruf tersebut. Gelombang ini ditemui di atas korteks sensorimotorik pada posisi channel C3 dan C4. Beberapa peneliti menyebut gelombang ini sebagai gelombang alfa rolandik sebab ditemukan pada posisi di fissura rolandik di garis tengah atas kepala dari arah anteroposterior.Gelombang ini dapat meningkat saat subyek yang diteliti tidak melakukan gerakan motorik (Kropotov, 2009).

Gelombang alfa yang lain ditemukan pada daerah oksipital yakni daerah kepala belakang di atas kuduk. Karena korteks oksipital merupakan pusat sensorik visual, maka dalam keadaan mata terbuka gelombang ini akan terepresi. Bila subyek yang diteliti membuka mata maka aktivitas gelombang alfa di daerah oksipital meningkat kembali.

Kajian penting berikutnya dalam EEG adalah ERP. Ada 3 hal yang perlu diperhatikan dalam hal ini yakni: amplitudo, latensi dan distribusi kepala. Aspek amplitudo melihat perubahan kekuatan (amplitudo) ERP pada rekaman EEG sebelum dan setelah rangsangan. Latensi melihat kapan 
puncak amplitudo terjadi. Distribusi kepala memperhatikan pada lokasi mana ERP dianalisis, masingmasing posisi terkait dengan fungsi otak tertentu.

Sinyal ERP dapat memiliki potensial listrik positif atau negatif. Bila positif ia ditandai dengan huruf $P$ dan $N$ jika negatif. Salah satu sinyal ERP yang penting adalah P300. Angka tiga ratus menunjukan latensi dicapai di waktu 300 ms setelah rangsang. Gelombang ERP P300 merepresentasikan aktivitas kognitif seperti orientasi atensi (Sanei \& Chambers, 2007).

Sinyal EEG diperoleh melalui sadapan sejumlah channel umumnya bisa 20, 32, 64 atau lebih. Pada penelitian ini digunakan sadapan 32 channel (posisi channel lihat Gambar 1). Selain AKI, sinyal yang diperoleh umumnya diproses dengan analisis Fourier yang mentransformasi fungsi dari yang berargumen waktu ke yang berargumen frekuensi. Transformasi Fourier bermanfaat untuk memperoleh spektrum kekuatan (power spectrum) sinyal.Analisis waktu-frekuensi (time frequency analysis) dapat melihat dominasi atau perubahan amplitudo (kekuatan) frekuensi dari waktu ke waktu.

\section{ILUSTRASI KASUS}

Pada bagian ini kami akan menampilkan ilustrasi kasus penerapan AKI pada pemrosesan sinyal EEG. Dataset EEG diambil dari daring yang terbuka untuk publik pada alamat situs https://sccn.ucsd.edu/ arno/fam2data/publicly_available_EEG_data.html.

Adapun dataset yang digunakan adalah dataset Psychophysics dengan 1 subyek penelitian yang menjalani 80 kali stimulasi visual dengangambar bentuk bujur sangkar.Rekaman EEG dibagibagi berdasarkan 80 epos (epoch) setiap stimulus gambar bujur sangkar ditayangkan kepada subyek. Setiap epos dimulai dari 1 detik sebelum stimulasi (-1000 ms) hingga 2 detik setelah stimulasi (1992 ms). Rekaman EEG diambil melalui 32-channels.

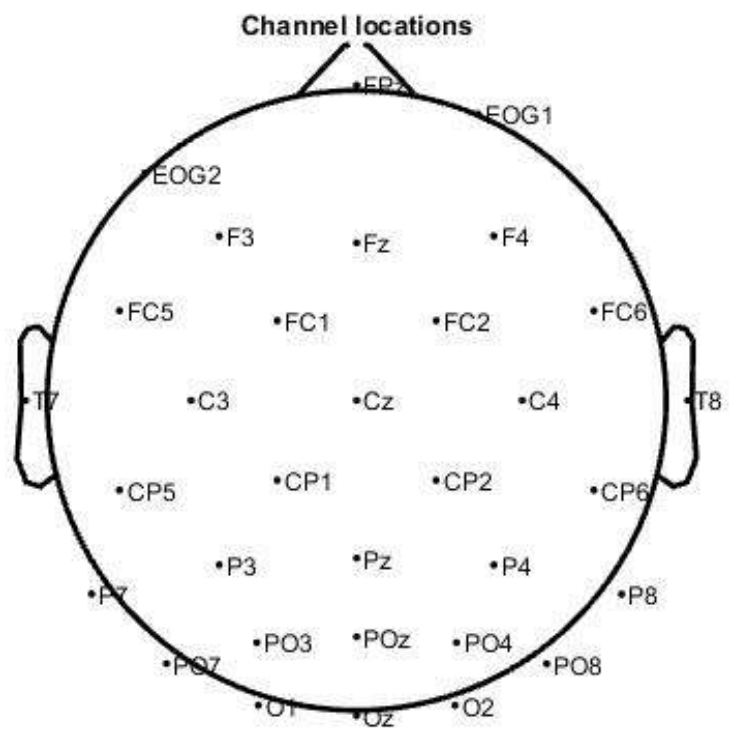

32 of 32 electrode locations shown

Gambar 1. Posisi 32 channel EEG 
Data akan diolah dengan menggunakan perangkat lunak pemrosesan sinyal EEGLAB yang merupakan modul ekstensi dari Matlab. Peneliti menggunakan Matlab versi 2015a dengan versi eeglab14_1_2b. Algoritma AKI pada EEGLAB yang digunakan adalah runica yang menggunakan pendekatan infomax Bell-Sejnowski (Delorme \& Makieg, 2004).

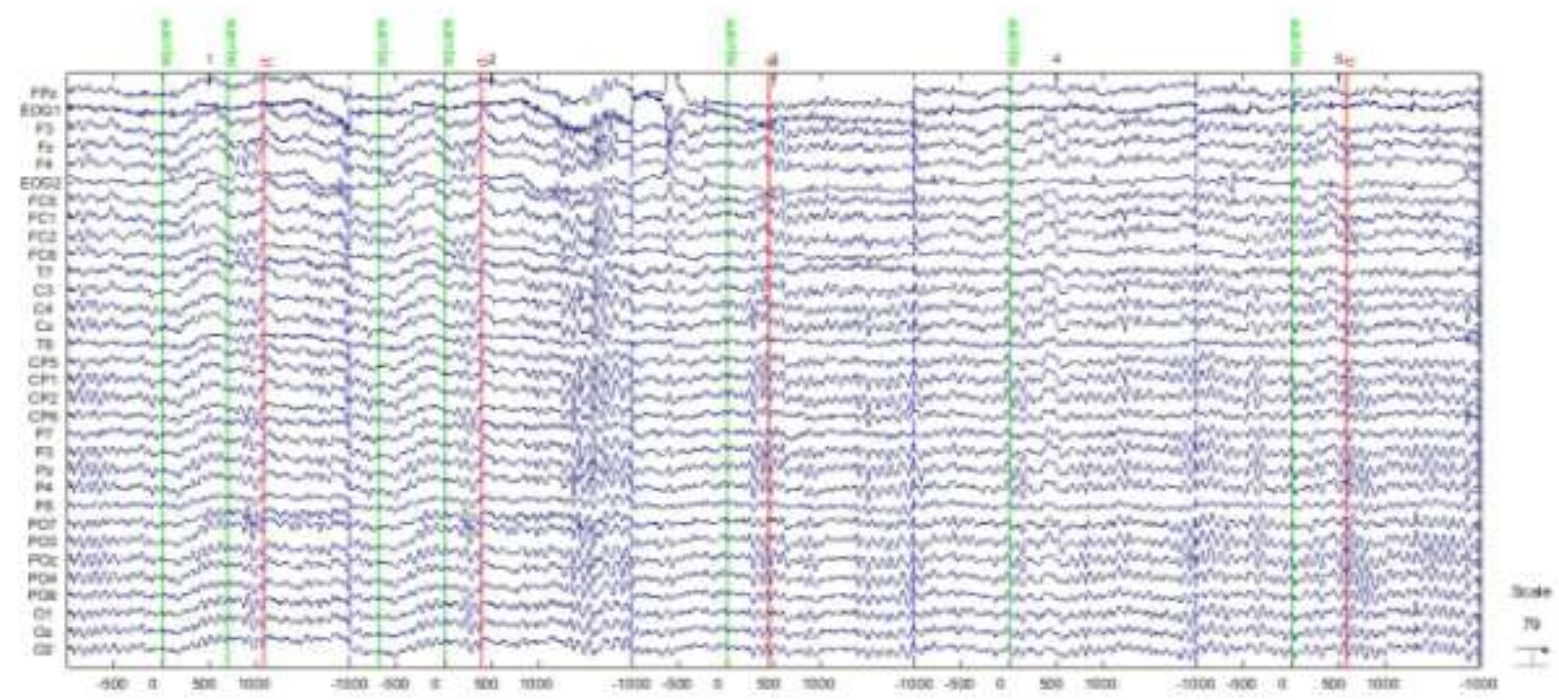

Gambar 2. Cuplikan data awal EEG 5 epos pertama. Waktu stimulasi visual gambar bujur sangkar ditandai dengan garis vertikal hijau dinamai square.

Pada Gambar 2 terlihat gelombang alfa yang mendominasi pola EEG kecuali pada channel EOG 1 dan 2 yang merekam otot mata. Pada epos ketiga di sekitar -500 ms terlihat lonjakan yang diduga sebagai artefak otot mata (Stern, 2013) yang polanya muncul pada bentuk dan waktu yang sama pada setiap channel, hanya saja kekuatannya semakin mengecil pada channel yang menjauhi mata. Kita juga melihat bahwa secara umum pola EEG yang terbentuk pada satu channe/kurang lebih tersalin pada channel lainnya.

Dengan menjalankan perintah runica pada EEGLAB maka dilakukan pemisahan komponen independen pada data EEG awal dengan menggunakan algoritma infomax Bell-Sejnowski. Berbeda dengan data awal EEG, AKI akan menghasilkan komponen independen saling berbeda satu sama lain.

Gambar 3 yang menampilkan komponen independen memperlihatkan bahwa pola EEG yang muncul pada setiap channel tidak serta merta memperlihatkan bentuk dan pola yang sama. Pola artefak otot mata yang dicurigai kini terlokasir hanya muncul pada komponen independen kedua, tepatnya pada epos 3 di waktu sekitar $-500 \mathrm{~ms}$. 


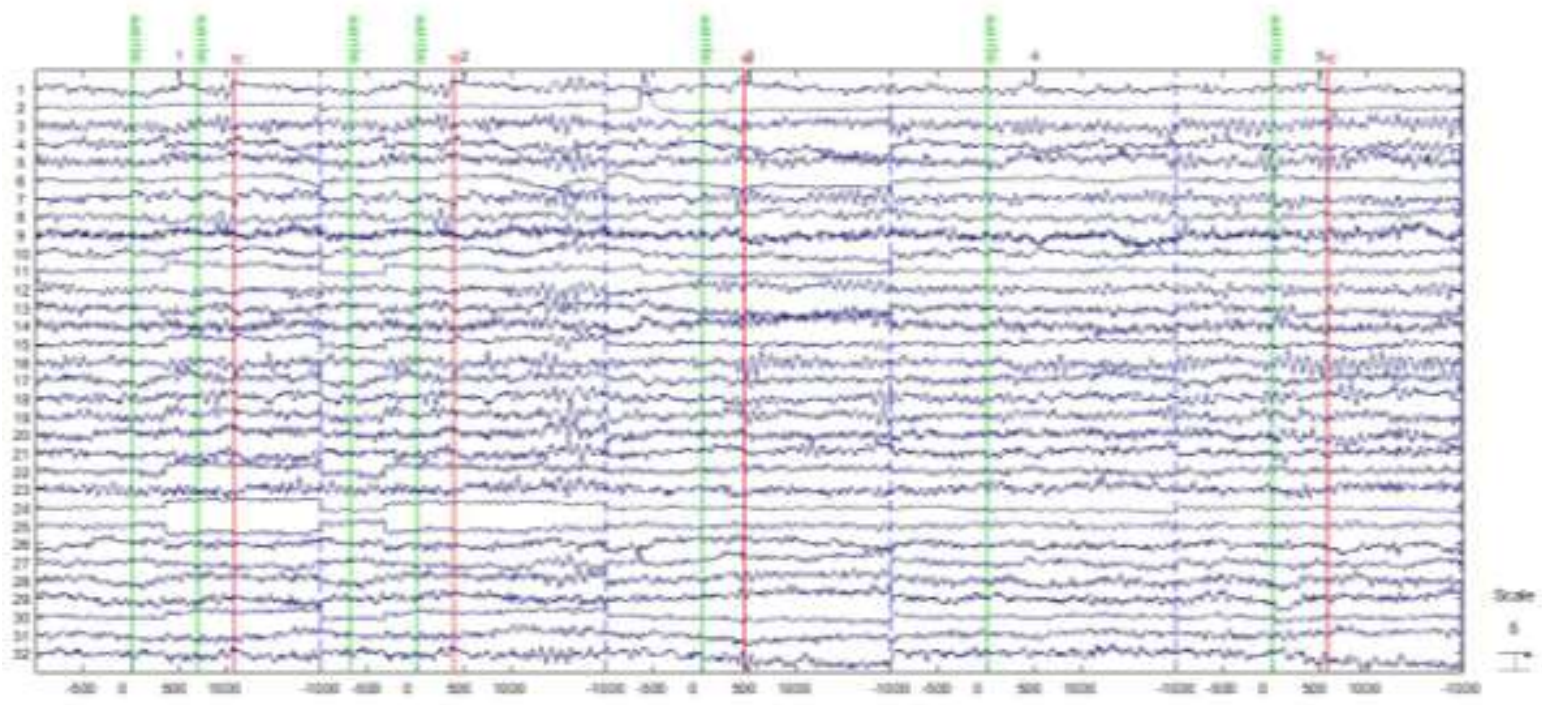

Gambar 3.Cuplikan komponen independen dari data EEG awal.
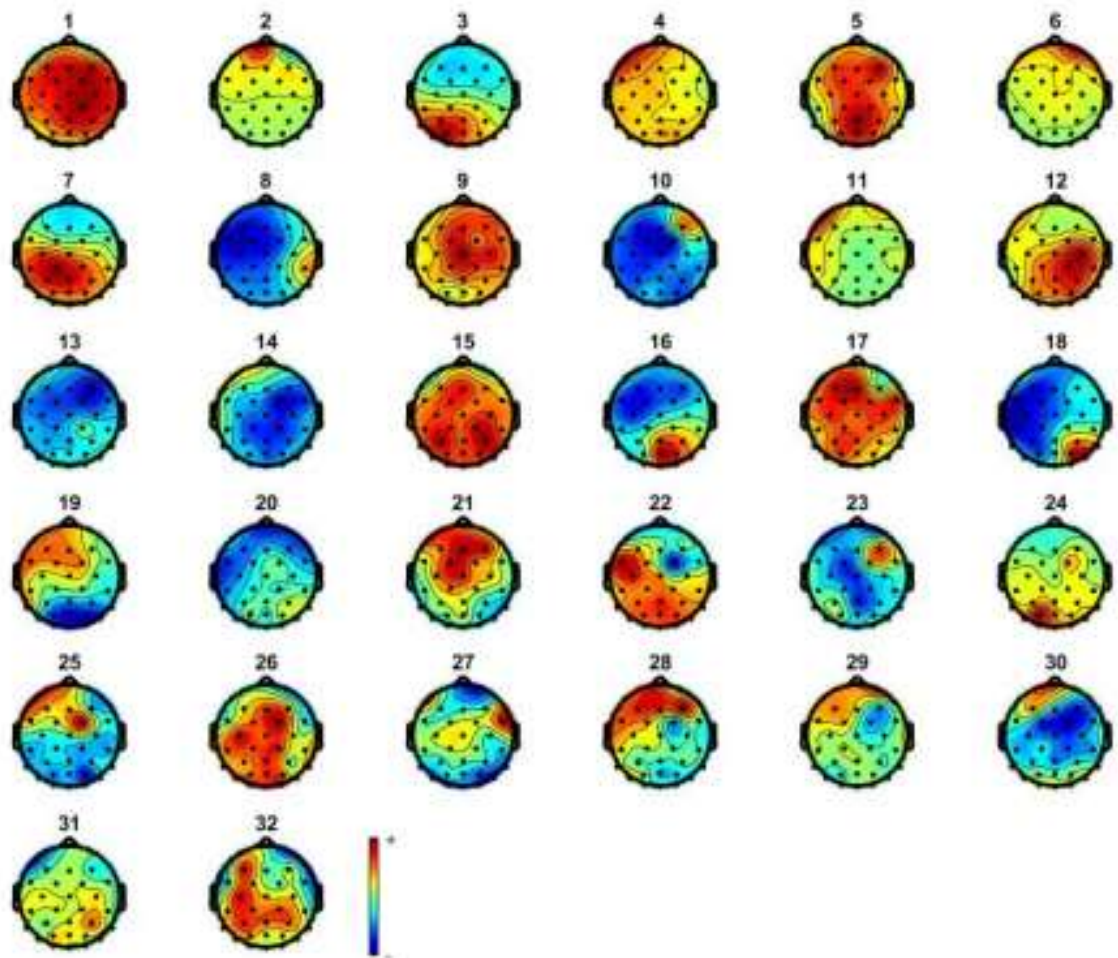

Continuous EEG Data epochs

Gambar 4.Topografi komponen independen. 
EEGLAB juga menyediakan feature topografis yang berfungsi untuk memetakan distribusi spektrum kekuatan komponen independen. Gambar 4 menampilkan pemetaan topografis ketiga puluh dua komponen independen. Terlihat bahwa komponen independen kedua yang dicurigai artefak otot mata dominan di daerah sekitar channel FPz dan EOG2. Hal ini tentunya memperkuat dugaan akan artefak otot mata tersebut.

Gambar 5 menampilkan spektrum kekuatan (power spectrum) channel terkait. Spektrum channel FPz masih memperlihatkan spike pada frekuensi $10 \mathrm{~Hz}$ sedangkan hal tersebut tidak ditemui pada spektrum komponen 2. Dan dari segi statistik data channel FPz lebih mendekati kenormal daripada komponen 2. Hal ini sejalan dengan teori bahwa sinyal EEG awal merupakan sinyal campuran yang distribusinya semakin mendekati distribusi normal, sedangkan komponen independen memaksimalkan ketidaknormalan (non-gaussian) distribusi data.

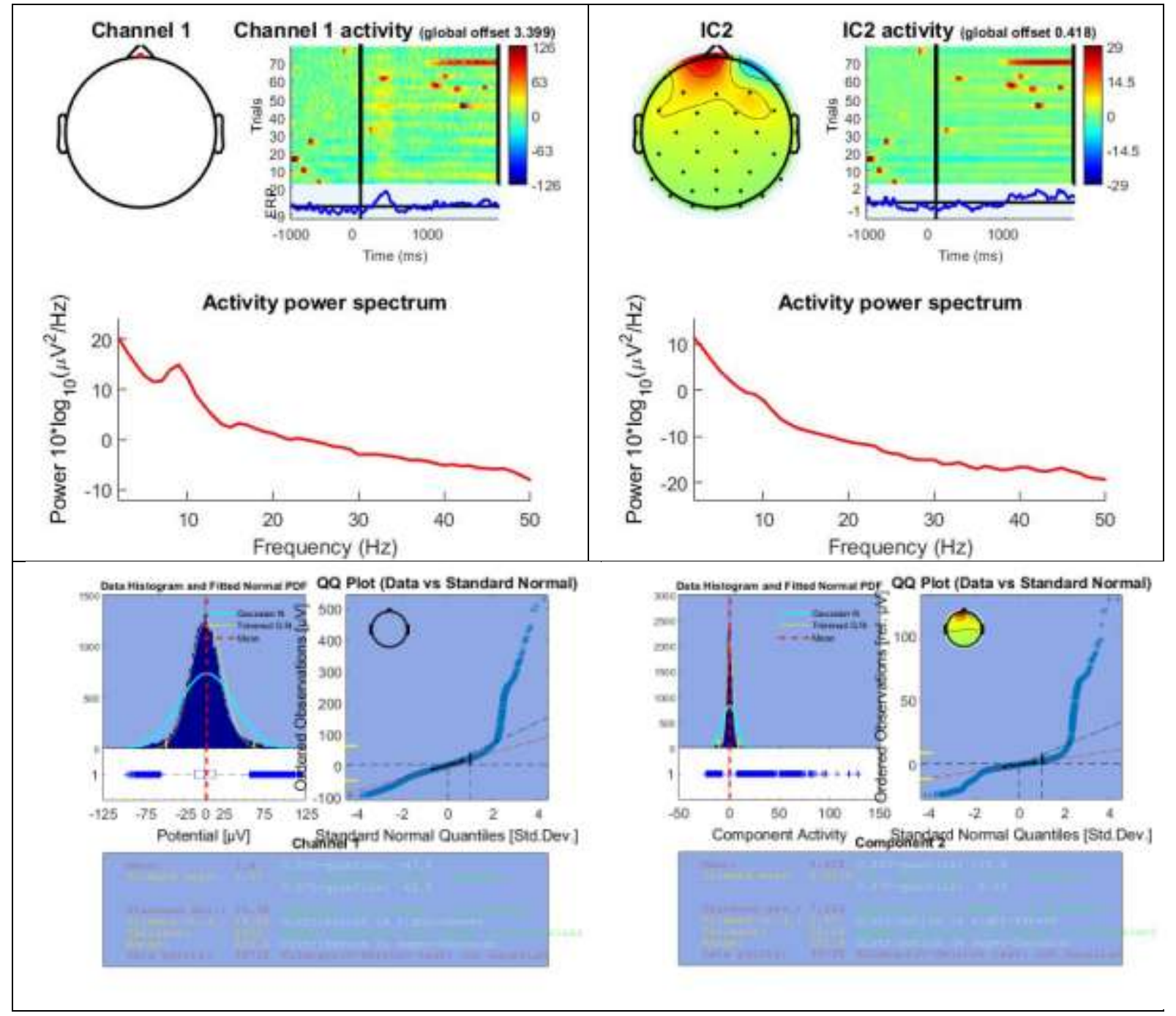

Gambar 5. Perbandingan spektrum kekuatan dan statistik channel FPz dan komponen 2 
Terakhir akan ditampilkan kajian ERP antara sinyal EEG dari channel FPz dengan komponen independen 2. Pada Gambar 6 memperlihatkan bahwa ERP channel FPz masih memperlihatkan pola klasik lonjakan P300 sebagai penanda respons kognitif. Akan tetapi respons P300 tersebut hampir menghilang pada ERP komponen 2.

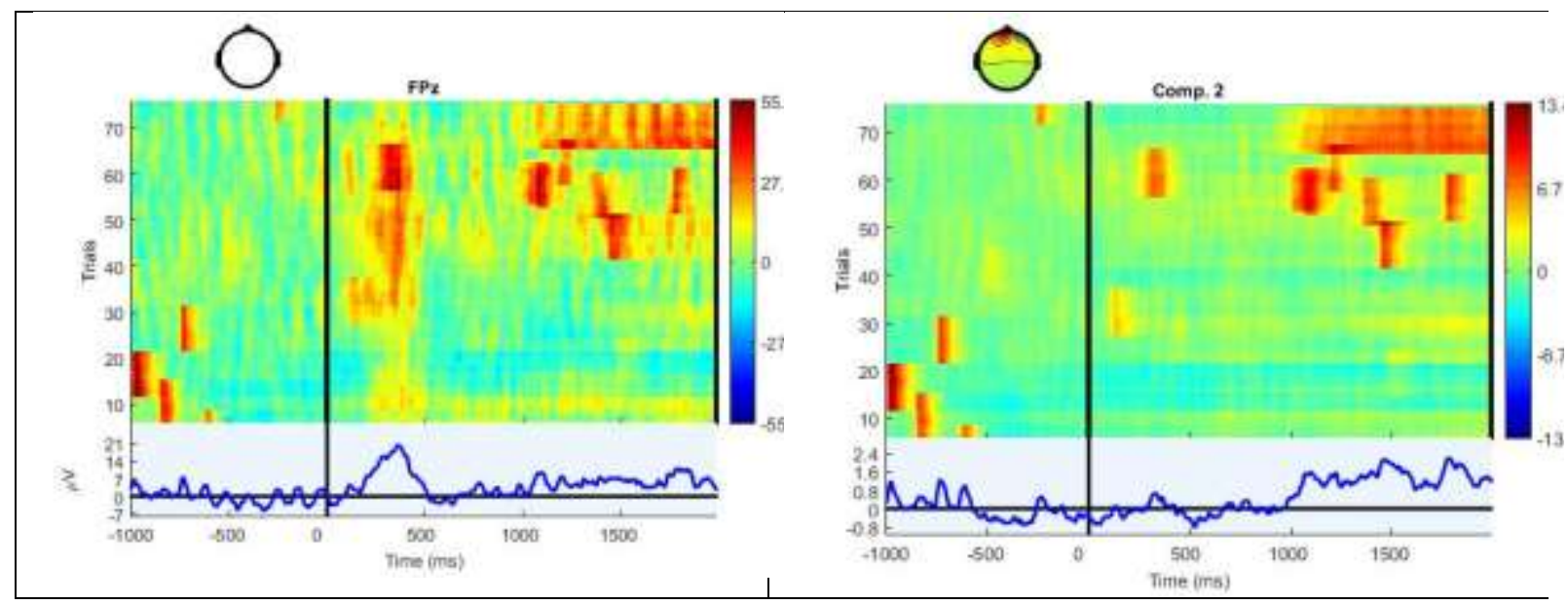

Gambar 6. Perbandingan ERP antara sinyal EEG dari channel FPz dan komponen indepenen 2

\section{SIMPULAN}

Kesimpulan dari kajian ini adalah bila penelitian hanya mengkaji EEG dari data awal (kasar) tanpa melakukan AKI, maka sulit untuk memilah-memilah mana yang benar-benar merupakan sinyal otak dari lokasi tertentu dan mana yang bukan merupakan sinyal otak dari lokasi tersebut. Dalam ilustrasi di atas diperlihatkan bahwa artefak otot mata masuk pada rekaman EEG pada setiap channel.Dengan melakukan AKI maka artefak otot mata tersebut dilokalisasi pada salah satu komponen independen.

Selain itu pada rekaman EEG yang tanpa diproses dengan AKI pola EEG yang tercetak hampir homogen di setiap channel seperti pada ilustrasi kasus di atas (Gambar 2) gelombang alfa hampir muncul pada bentuk dan waktu yang sama atau sinkron. Sedangkan pada AKI kita memperoleh gelombang alfa yang meski muncul pada banyak channe/ namun bentuk dan terlihat tidak sinkron. Dengan demikian permrosesan dengan AKI memungkinkan kita mendapatkan sinyal sumber tanpa terdistorsi atau tercampur dengan sinyal dari sumber lainnya sehingga hal ini dapat meningkatkan akurasi kajian atau analisis.

\section{REFERENSI}

Bell, A. J., \& Sejnowski, T. J. (1995). An information-maximization approach to blind separation and blind deconvolution. Neural Computation, 7, 1129-1159.

Comon, P. (1994). Independen component analysis - a new concept?. Signal Processing, 36, 287314.

Cover, T. M., \&Thomas, J. A. (2006). Elements of Information Theory.2nd Edition. Wiley.

Delorme, A., \& Makieg, S. (2004). EEGLAB: An open source toolbox for analysis of single trial EEG dynamics including independent component analysis. Journal of Neuroscience Method, 134, 9-21. 
Golub, G., \& Van Loan, C. (1996). Matrix Computation. 3rd edition. The John Hopkins University Press.

Hérault, J., \& Jutten, C. (1986). Space or time adaptive signal processing by neural network models. AIP. Conf Proc. 151, 206

Hyvärinen, A., Karhunen, J., \& Oja, E. (2001). Independent Component Analysis.John Wiley \& Sons. Kerami, D., \& Silaban, R M. (2009). Riset Operasional I. Penerbit Universitas Terbuka.

Kropotov, J. (2009). Quantitative EEG, Event-Related Potentials and Neurotherapy. Academic Press-Elsevier.

Papoulis, A. (1996). Probabilitas, Variabel Random, Dan Proses Stokastik. Edisi Kedua. Gajah Mada University Press.

Rao, C. R. (2002). Linear Statistical Inference and Its Application. Second Edition. Wiley.

Sanei, S., \& Chambers, J. A. (2007). EEG Signal Processing. Wiley.

Stern, J. M. (2013). Atlas of EEG Paterns.2nd Edition. Wolters Kluwers - Lippincott Williams \& Wilkins.

Stone, J. V. (2004). Independent Component Analysis. A Tutorial Introduction. A Bradford Book. MIT Press.

Widodo, T. S. (2012). Instrumentasi Biomedis.Analisis Sinyal dan InstrumenTerapi.Yogyakarta: Graha llmu. 